\title{
Using mobile audience response systems to enhance medical education: a medical student perspective
}

This article was published in the following Dove Press journal:

Advances in Medical Education and Practice

5 May 2017

Number of times this article has been viewed

\section{Faisal Siddiqui \\ Ithsham Iqbal \\ Saeed Azizi}

Faculty of Medicine, St George's Hospital Medical School, London, UK
Correspondence: Faisal Siddiqui Faculty of Medicine, St George's Hospital Medical School, Cranmer Terrace, London SWI7 ORE, UK

Email faisal_s250@hotmail.co.uk

\section{Dear editor}

We read with great interest the article of Abdel Meguid and Collins ${ }^{1}$ that analyzes students' perceptions of audience response systems (ARS) use in undergraduate education. We strongly agree with the potential of ARS, and as current medical students, we would like to offer our perspective on their application in medical schools.

The article highlights the benefits of implementing interactive learning techniques. While lectures remain integral to medical education, researchers have questioned their efficacy in comparison to more active learning methods. ${ }^{2}$ ARS certainly provides a method of making traditionally didactic lectures far more interactive. The advantages of this have been highlighted by Miller and Metz ${ }^{3}$ who found that students taught through interactive lectures scored $22.9 \%$ higher in their final examination than those taught with didactic lectures.

From our perspective, we have experienced the benefits of being taught using mobile ARS and can vouch for their effectiveness. We agree with the importance of open-ended questions as mentioned in the Abdel Meguid and Collins ${ }^{1}$ article. For us, questions requiring critical thinking were much more beneficial than simple recall questions (although these also had value) and often sparked productive conversation surrounding the reasoning of responses. In addition, many ARS applications consist of more diverse question types, including the use of images from which students can select a specific region as a response. This would be particularly useful in anatomy, which was one of the modules upon which this study was based.

Using ARS to review previous learning concepts was also invaluable and provided immediate feedback on the audience's understanding - as mentioned in the Abdel Meguid and Collins ${ }^{1}$ article. By starting a lecture with a short quiz covering previously taught content, lecturers could assess our level of understanding of a given topic and thus tailor the session to areas that were identified as needing more attention. With applications such as "Mentimeter" offering the ability to directly export feedback to Excel, further analysis of data can be completed retrospectively - possibly allowing institutions a valuable insight, which may influence future teaching. Utilizing such applications may also address the issue of educators not receiving enough regular feedback. ${ }^{4}$

Although ARS can be useful methods of teaching, we feel that it is important to mention some of the barriers to their implementation that have not been explored by the authors. 
Battery usage will be increased, and problems may arise for students who have not charged their phones before sessions. Improving the battery life of newer smartphones, together with the availability of portable power banks, may go some way to ease this burden, and with charging stations becoming prevalent in many public places, there is no reason why the same could not be said for universities.

With a large amount of time often dedicated to a relatively small number of questions when using ARS, there is also the likelihood of being distracted by other smartphone applications such as messaging and social media. This problem, however, will be present irrespective of smartphones being used as a teaching tool and may even be less prevalent if students are more engaged with the session through their smartphones.

Another possible drawback relates to students who may not possess a capable smartphone - with medical schools potentially having to provide devices or financial support for such students. With that said, there already exists a high degree of smartphone ownership and use as well as a positive attitude toward their educational application among medical students. ${ }^{5}$ We have also noted that medical schools in the UK are providing their students with personal devices to assist with their medical education ${ }^{6}$ or expecting their students to have their own capable devices as is the case in our own medical school.

In conclusion, we agree with Abdel Meguid and Collins $^{1}$ that when used effectively, ARS can have a significant role in higher education, and their study - together with our own experience in medical school - strongly supports this. While there are potential limitations to widespread ARS use in medical education, there is no reason why these cannot be overcome. The days when lecturers politely request students to put away their phones may soon come to an end, with the opposite instead being requested.

\section{Disclosure}

The authors report no conflicts of interest in this communication.

\section{References}

1. Abdel Meguid E, Collins M. Students' perceptions of lecturing approaches: traditional versus interactive teaching. Adv Med Educ Prac. 2017;8:229-241.

2. Richardson D. Don't dump the didactic lecture; fix it. Adv Physiol Educ. 2008;32(1):23-24.

3. Miller CJ, Metz MJ. A comparison of professional-level faculty and student perceptions of active learning: its current use, effectiveness, and barriers. Adv Physiol Educ. 2014;38(3):246-252.

4. Gray TG, Hood G, Farrell T. The results of a survey highlighting issues with feedback on medical training in the United Kingdom and how a Smartphone App could provide a solution. BMC Res Notes. 2015;8:653.

5. Payne KFB, Wharrad H, Watts K. Smartphone and medical related App use among medical students and junior doctors in the United Kingdom (UK): a regional survey. BMC Med Inform Decis Mak. 2012;12:121.

6. Gidda M. Students: Bring Your Own Technology to Uni. The Guardian; London: 2014. 


\section{Authors' reply \\ Eiman M Abdel Meguid' \\ Matthew Collins ${ }^{2}$}

'Centre for Biomedical Sciences Education, School of Medicine, Dentistry and Biomedical Sciences, ${ }^{2}$ Centre for Computer Science, School of Electronics, Electrical Engineering and Computer Science, Queen's University Belfast, Belfast, Northern Ireland, UK

Correspondence: Eiman M Abdel Meguid

Centre for Biomedical Sciences Education, School of Medicine, Dentistry and Biomedical Sciences, Queen's University Belfast, Whitla Medical Building, 97 Lisburn Road, Belfast BT9 7AE, Northern Ireland, UK

Tel +442890972148

Email e.abdel-meguid@qub.ac.uk

\section{Dear editor}

It is very heartening to read such a positive response to the article from current students. It validates the observations we had ourselves on the degree of appreciation students have for this method of teaching and some good scope for potential areas of further development in its application.

Certainly, as they point out themselves, there are a range of other question types that can be explored, and the more open-ended ones are likely the most appropriate to encourage a deeper level of engagement with the material beyond surface learning. They mention a similar audience response system (ARS), Mentimeter, and a quick look at this site indicates that it has a similar feature set to Poll Everywhere, which we used ourselves, simply because it happens to be the one our institution has a contract to use. The particular choice of system is ultimately immaterial, but in terms of dissemination of good practice, the key takeaway is in finding creative ways to use it and add interactively to the learning environment. The idea of using the data export functionality that many of these systems offer for later offline analysis to provide greater insight into student understanding is certainly worth exploring, particularly if these findings are explored in subsequent lectures, with a view to strengthening the provision of formative feedback to support student learning.

These types of packages are clearly appreciated by students and as such should be strongly considered by academicians who should be encouraged to take the time to experiment with their setups and become comfortable with their use. The investment of time and effort they put in, though we should acknowledge that some academicians (especially when not coming from an Engineering or Computer Science background) are not as enthusiastic about embracing technology as perhaps the students they have in front of them, is rewarded by the increased engagement levels of the students observed.

\section{Disclosure}

The authors report no conflicts of interest in this communication.

Dove Medical Press encourages responsible, free and frank academic debate. The content of the Advances in Medical Education and Practice 'letters to the editor' section does not necessarily represent the views of Dove Medical Press, its officers, agents, employees, related entities or the Advances in Medical Education and Practice editors. While all reasonable steps have been taken to confirm the content of each letter, Dove Medical Press accepts no liability in respect of the content of any letter, nor is it responsible for the content and accuracy of any letter to the editor.

\section{Publish your work in this journal}

Advances in Medical Education and Practice is an international, peerreviewed, open access journal that aims to present and publish research on Medical Education covering medical, dental, nursing and allied health care professional education. The journal covers undergraduate education, postgraduate training and continuing medical education

\section{Dovepress}

including emerging trends and innovative models linking education, research, and health care services. The manuscript management system is completely online and includes a very quick and fair peer-review system. Visit http://www.dovepress.com/testimonials.php to read real quotes from published authors. 